\author{
Economics Working Paper Series
}

2017/013

\title{
Concurrent Elections and Political Accountability: Evidence from Italian Local Elections
}

\author{
Emanuele Bracco and Federico Revelli
}

The Department of Economics

Lancaster University Management School

Lancaster LA1 4YX

UK

(C) Authors

All rights reserved. Short sections of text, not to exceed two paragraphs, may be quoted without explicit permission, provided that full acknowledgement is given. 


\title{
Concurrent Elections and Political Accountability: Evidence from Italian Local Elections*
}

\author{
Emanuele Bracco $^{\dagger} \quad$ Federico Revelli ${ }^{\ddagger}$
}

May 9, 2017

\begin{abstract}
This paper analyses the effects of holding concurrent elections in multi-tiered government structures on turnout decision and voting behaviour, based on municipal and provincial electoral data from Italy during the 2000s. When the less-salient provincial elections are held concurrently with the highly salient municipal elections, we observe three main effects: (1) turnout increases significantly by almost ten percentage points; (2) issues that are specific of the more salient (mayoral) contest affect the less salient (provincial) contest, with mayors' fiscal decisions impacting on the vote share of provincial incumbents; (3) issues that are specific to the less salient (provincial) contest stop affecting provincial elections outcomes. These findings shed light on how voters acquire information on incumbent politicians, and proves that the effectiveness of an election as an accountability tool may be hindered by the concurrence with higher-stakes elections.
\end{abstract}

JEL classification: D70, H70.

Keywords: concurrent elections, turnout, political accountability, local elections, coattails.

\section{Introduction}

Observing the rates of voter turnout at different elections and in different countries, one can notice how voters around the globe show markedly changeable levels of interest for different contests. Typically, general and presidential elections are more likely to spur debate and mobilize voters than regional and local elections. Referenda can instead see either very low turnout, as in the Catalan independence ballot of 2014 or the Hungary referendum on EU

\footnotetext{
${ }^{*}$ We would like to thank seminar participants to SIEP2015 in Ferrara, 2nd Lille Workshop in Political Economy, and particularly Edoardo di Porto, Eva Mork and Federico Boffa. All errors are our own.

$\dagger^{\dagger}$ Department of Economics, Lancaster University Management School, LA1 4YX, Lancaster, United Kingdom. Email: e.bracco@lancaster.ac.uk

${ }^{\ddagger}$ Department of Economics and Statistics "Cognetti de’ Martiis". Università di Torino.
} 
refugee quotas of 2016, or impressive levels of participation as in the Scottish Independence referendum in 2015 or the one on exiting the European Union in UK in 2016.

Within countries that hold elections on separate dates, turnout rates tend to differ significantly too. For example, $72 \%$ of voters turned out for the 2016 Brexit referendum in the UK, more than for the 2015 UK general elections (66\%), and more than twice as much as for the 2014 European Parliament and local elections (35\%). In other countries, such as the United States, with around 500,000 elected officials in almost 90,000 representative local governments and school districts, local elections are either held separately or concurrently with state and national elections on "Election day." In the latter case, holding low salience (local) and high salience (presidential) elections concomitantly tends to raise the rate of turnout for the low-salience elections - an effect that is generally welcomed by academics and policy-makers alike that take higher turnout as a symptom of a better functioning democracy.

In fact, as long as voters rationally compare the costs and returns to voting when deciding whether to turn out or not, and given that the cost of going to the polls is only paid once in case of concurrent elections, we should expect voter turnout to be higher in "election days." However, holding different elections simultaneously is unlikely to only have the effect of raising the rate of voter participation for all races. Two distinct phenomena are typically observed that can be attributed to the fact of holding the elections concomitantly. The first is the so-called "roll-off", i.e. instances in which voters rationally choose to abstain in some contests and cast a valid ballot in others, thus frustrating the objective of raising participation per se in simultaneous races. The second one - called "coat-tail voting" — arises when the popularity of a candidate in one contest spills over to the co-partisan candidate in another contest. In circumstances where voters show different levels of involvement in electoral races with varying stakes and salience, one can therefore expect that holding elections simultaneously might have ambiguous consequences on the accountability of governments: with concurrent elections, the voting decision for the less salient contest might be indirectly affected by the factors and issues that are at stake in the more salient concurrent one. This further weakens the impact of own performance on popularity and loosens the accountability mechanism as far as lower salience races are concerned- a consequence of coat-tail effects in concomitant elections that does not seem to have been fully recognized before.

In order to test these hypotheses about the effects of concomitant elections, we analyze a newly constructed dataset on Italian local elections and public finance data. In particular, we use data on all municipal and provincial elections that were held in 2004 and 2009 in Italy, and exploit the staggered features of municipal elections: the independent nature of each municipality's mayoral term implies that within each province going for provincial elections (the upper tier of local government in Italy), some voters were also called to vote 
on the more salient mayoral elections (the lower tier of local government) due to the larger set of competencies attributed to municipal authorities than to provincial ones. In the rest of municipalities constituting the control group, voters were only voting for renewing provincial governments in lower stakes elections. This allows us to have an original quasi-experimental design in which treatment (being subjected to concurrent mayoral and provincial elections) and control group (voting solely for provincial elections) can be considered as good as randomly assorted. We analyse the levels of turnout and the voting behaviour in provincial elections at the municipal level. In particular we are interested in ascertaining whether: (1) the concomitance of mayoral elections raises turnout in provincial elections too, and: (2) voters take into account fiscal performance when voting, and how concurrence of elections affects this capacity. In particular, we test the impact of provincial as well as municipal fiscal issues on provincial election outcomes. Our results can be briefly summarized as follows. First, we find turnout rates to be significantly higher in the treatment group (concomitant provincialmunicipal elections) by almost ten percentage points, and valid votes to be higher by about six percentage points. Second, we get evidence of how concurrence substantially affects the relationship between fiscal peformance and voting behaviour: provincial fiscal performance affects provincial voting behaviour only in the control group (no concurrent elections), while municipal fiscal performance affects provincial voting behaviour only in the treatment group (concurrent municipal and provincial elections).

The paper is organized as follows: Section 2 goes through the related literature, Section 3 describes the theoretical background, Section 4 illustrates the institutional setup, and Section 5 discusses the data and the empirical strategy. Section 6 shows the empirical results, Section 7 the robustness checks and Section 8 concludes.

\section{$2 \quad$ Related Literature}

This paper relates to a number of strands of literature. First of all the literature on turnout in elections, and its link with information acquisition. Secondly on the literature on strategic abstention and rational delegation. Lastly, it links with the papers on the effect of information on voting behaviour, including the so-called coat-tail effect.

Many authors looked into the rationality of turning out in elections (for a review see Dhillon and Peralta (2002)). In particular, some aimed at understanding whether a higher turnout is desirable or not, as higher turnout may imply that less-informed voters contribute relatively more to the electoral outcome, and it may be on aggregate more "expensive" as more voters pay the cost of voting. Ghosal and Lockwood (2009) look into an instrumental voting model in which elections are both a common and private value contest. Gerardi 
et al. (2009); Martinelli (2006, 2011); Krasa and Polborn (2009) instead look into privatevalue elections and the efficiency effects of increasing turnout when voters are instrumental. Bhattacharya et al. (2014), Borgers (2004) look instead on the effects of compulsory voting rules on the efficiency of elections.

Our paper also relates with the issue of strategic delegation, i.e. when in common-value elections less informed voters decide to abstain in order to delegate the decision to more informed voters. Seminal paper on this issue is Feddersen and Pesendorfer (1996). Oliveros (2013) explored the interplay between information acquisition and abstention in private value elections, while Augenblick and Nicholson (2016) tested whether the positioning of contests on the ballot affects voting and turnout decisions.

The mechanism linking concurrent elections with the decision of voters on whether to vote or abstain is instead less explored, and even less attention has been devoted to how the stakes of one of the issues spill-over onto the other issues. As for the former, Ghirardato and Katz (2000) offers a decision-theoretic model in multiple elections in which voters may decide to abstain selectively, while Degan and Merlo (2007) look into two private-value elections, in which voters are regret-minimizer and gather information on the ideological position of candidates in different tiers. Their model treats the two tiers as practically independent, not offering many insights into the interaction between the two contests. In a broad sense also Matejka and Tabellini (2015) relates to our paper, as it describes rationally inattentive voters, who decide how to concentrate limited resources in the information gathering process about the electoral contests they are facing.

The empirical literature studying the consequence of holding elections for different tiers of government separately or concurrently is more developed, particularly as far as the impact on turnout is concerned. The intuition that concurrent elections can influence voter turnout has long been present in the political science literature, and has been offered as a solution to the dramatically low voter turnout rates that are often registered in US local government elections that are held off-cycle (Lijphart, 1997; Hajnal and Trounstine, 2005). Recent papers have explored the effects of on-cycle versus off-cycle elections on the outcomes of elections and on the policies that are implemented (Anzia, 2011; Anzia et al., 2012) and found that off-cycle elections cause low turnout, favoring lobbies and interest groups that are able in those elections to obtain more favorable policies than in high turnout concomitant elections. On the other hand, Berry and Gersen (2011) analyze the effects of election timing on voter turnout and policy-making by exploiting a 1980s change in the California Election Code, and find that the election timing reform raised voter turnout significantly, but had virtually no impact on public policy. Lo Prete and Revelli (2014) exploits concurrent elections as a source of exogenous variation in turnout, finding that higher turnout (and possibly therefore less 
informed voters) implies voting outcomes which are less responsive to changes in performance, and the election of lower-valence politicians. Other papers explored empirically the effect of simultaneous elections: Noury (2004) looks at roll-call data of Members of the European Parliament, focusing in particular on abstention choices; Degan and Merlo (2007) focus on the interplay between the ideologies of candidates using data from Congressional and Presidential elections in the US.

Finally, a number of papers have explored the issue of coat-tails in concurrent elections. Ahn and Oliveros $(2012,2014)$ look into how information aggregation in juries is affected by the choice of sequential or joint trials. Zudenkova (2011) sets up a political agency model in which with concurrent elections, in which politicians care about their own and their fellow partisan re-election chances; in such a setup the optimal voters' strategy is to hold each politician accountable for performances of all incumbents jointly, thus minimising incumbent's free-riding on each other's effort. Halberstam and Montagnes (2015) show that U.S. senators elected together with the President tend to be more partisan: according to their model a popular presidential candidate increases the chances of victory of co-partisan senatorial candidates, allowing them to be more extremists.

A voluminous literature has explored how voters retrospectively reward or punish politicians for past performance, though measuring government performance is well known to be a challenging task. The early economic tests of decentralized government accountability focused on the hypothesis that the generality of voters dislike public spending growth and debt accumulation, that is behave at the polls as fiscal conservatives (Peltzman, 1992). More recent research has pointed instead to the vote-buying power of at least some more visible public expenditure items, and investigated the electoral consequences of the mix and cycles of various categories of decentralized expenditures (Akhmedov and Zhuravskaya, 2004; Veiga and Veiga, 2007; Sakurai and Menezes-Filho, 2008; Drazen and Eslava, 2010; Jones et al., 2012).

Finally, some recent contributions have been able to ascertain the impact of more precise measures of local government performance on election results, like observed student performance scores as a measure of education quality in Israeli local governments (Brender, 2003), local authorities' performance rankings as evaluated by an indipendent commission in the UK based on audit and inspection activity and service quality indicators (Revelli, 2008), or the overall quality of life in Italian cities (Bianchini and Revelli, 2013).

Our crucial argument here is that the presence of a concurrent higher stakes election will hamper the accountability of elected representatives for the lower stakes contests because of the expectation that voting for those offices will respond less to the performance of the incumbent and more to the performance of the incumbent in the higher stakes tier. 


\section{Theoretical Background}

The theoretical underpinning of this paper can be ascribed to some ideas already explored in the literature. First, electoral competition (and elections in particular) are potentially useful tools to disseminate information on incumbent politicians and their challengers, and this is more true the more relevant is the electoral contest (see for example Wittman, 1989). If this is the case, we expect that, before a particular election, voters hold more information on that contest; in other words, when mayoral elections are looming, voters receive relatively more information about mayoral fiscal choices, which in turn may affect their voting behaviour (potentially in any contest).

The further issue is how voters use this information: whether they are able to interpret it correctly, and attribute it to the correct contest in case of concurrence. This goes back to Alesina and Rosenthal (1995) and Wolfers (2002) (among others) and the challenge to test voters' rationality: it is quite likely that voters hold politicians into account for things that are beyond politicians' control (e.g. economic growth, oil prices in oil producing localities). If this is the case, a higher level of taxation may push voters against incumbent politicians, whether each of them is responsible or not for the tax hike. In other words, we may expect that a tax cut by mayors (more salient contest) may advantage incumbent provincial presidents (less salient contest). If this were the case, we expect any tax hike to disadvantage all incumbent politicians.

Last, we need to consider whether party identity and ideology play a role in these dynamics. Following Geys and Vermeir (2008), we can imagine an environment in which both the individual politician and her party's organisation contribute to an administration's fiscal performance, thus generating a polity in which performances of administrations belonging to the same party are positively correlated. If this is the case, we should also expect that the effect of a tax cut by a mayor may have different effects to provincial election outcomes according to whether mayors and provincial presidents are politically aligned or not. This would imply that - for instance - a tax cut by a left-wing mayor would improve the electoral prospects of the left-wing provincial candidate, and worsen the ones of the right-wing candidate, irrespective of which one is the incumbent and which is the challenger.

\section{Institutional Background}

Italy is subdivided in twenty regions, about 100 provinces, and over 8,000 municipalities. The institutional framework is such that about $70 \%$ of public spending is done by the central government, $20 \%$ by regions (mostly on healthcare), almost $2 \%$ by provinces (mostly on 
local roads, environment, vocational training and school buildings), and the remaining $8 \%$ by municipalities (on primary schools, social services, environment, local transport). This paper focuses on provinces and municipalities.

Looking both at turnout and voters' knowledge of the different tiers of government, we can state that the top and bottom tiers are the one that receive more attention: voters are generally much more aware of who is their mayor, than on who is the provincial or regional president. Similarly, turnout is highest for general elections, and it correlates with the share of public spending of each tier, so that the ranking follows with mayoral, regional, provincial and finally European elections.

A further issue that is notable of attention is a practical aspect of the electoral mechanism. No postal vote is allowed for local elections. When at the polling stations, voters are given separate ballots for each electoral contest. It is practically feasible for voters to refuse some of the ballots and vote only in a subset of the contests, but it is an extremely rare event. More often voters may take all ballots, but decide to spoil or leave blank some of them. ${ }^{1}$

Regional Presidents, Provincial Presidents and Mayors are directly elected together with their respective councils, remain in power for 5 years, and can be re-elected only once. Elections are generally held once a year, and each year a number of municipalities, provinces, and regions goes to elections. This is because if a president/mayor resigns, dies, or loses a confidence vote in the council, elections are called for the following Spring and a new mayor or President is elected for a full five-year term. In time this generated independent terms of office across space and tiers. Provincial presidents and mayor of municipalities with more than 15,000 inhabitants are directly elected with a runoff system, ${ }^{2}$ while mayors of smaller municipalities are elected with plurality rule.

Each tier of government finances its expenditures through own taxes, charges, and grants from upper tier governments. Municipalities are relatively less reliant on grants than provinces, as they have access to larger tax bases and levy more charges. As an example, Tables 1-2 shows the share of current revenues from taxes, grants, and other charges for provinces and municipalities in year 2004. Both provinces and municipalities receive most of the grants from central and regional government. Municipalities receive hardly any transfer from provincial governments, making the two tiers independent from the budgetary point of view.

Municipalities' main tax revenue source is a property tax (ICI), which is levied on all properties. Its tax base is the land registry value of each property, and its tax rate is freely

\footnotetext{
${ }^{1}$ For example in the 2004 mayoral and provincial elections of Florence, within the municipality of Florence out of over 230,000 voters and over 300,000 eligible citizens the difference in turnout between mayoral and provincial elections accounted to 86 voters.

${ }^{2}$ If no candidates obtains an absolute majority of votes in the first round, a second round of elections is called between the top two candidates of the first round. The candidate winning the second round is elected.
} 
decided by each mayor within a band. This tax has been at the forefront of the political debate, so much so that its abolition or reduction has proven to be a successful electoral promise in more than one instance. ${ }^{3}$ Provinces own revenues are instead mostly coming from a tax on new car registrations, on car insurance policies and on electricity consumption; for each of these levies each province decides the tax rate within a centrally set band. The nature of these taxes also implies that it is near impossible for a provincial government to target provincial taxation towards (or away from) specific municipalities for electoral reasons.

In terms of expenditures, the two main spending chapters for both tiers are general administration and education, with municipalities taking care of primary schools, and provinces taking care of secondary schools (mainly building maintenance and ancillary services). Table 1-2 shows the main expenditure components in each tier for year 2004.

Our choice to focus on provinces and municipalities is motivated by a number of reasons. First of all, we are interested in analyzing the electoral outcome of second-tier elections, and provincial elections are the least favoured by Italian voters. Secondly, the lower-tier / higher-salience quality of mayoral elections allows us to separate municipalities neatly into a treatment and a control group. Finally, regional elections are mostly held in years in which only a handful of municipalities are called to the polls, making our identification strategy unusable.

Most of provincial elections are held in years ending in 4 and 9 (59 provinces went for elections in 2004 and 55 in 2009). ${ }^{4}$ Over 4,500 municipalities are included in these provinces and - within these - about 3.000 mayors are running for election in the same years. This implies that we can observe the voting behaviour at the municipal level in over 4,500 municipalities, 3,000 of which are "treated" by having concurrent mayoral elections, and 1,500 are a natural "control" group, in which only the provincial elections are held.

\footnotetext{
${ }^{3}$ Ahead of 2006 general elections, the conservative incumbent Silvio Berlusconi promised exemption to resident-owners. This is believed to have contributed to narrow his electoral defeat. The (barely) winning left-wing coalition increased the tax allowance for resident-owners. When new elections were called in 2008, Silvio Berlusconi won and honoured his promise, exempting from the real-estate tax resident-owners living in non-luxury dwellings.

${ }^{4}$ Three provinces elected their president in 2004 and 2008: this was because their presidents decided to run for Parliament in 2008, and had to file early resignation as the two offices cannot be legally held contemporaneously. The Province of L'Aquila went to elections in 2004 and 2010; elections were planned for June 2009, but they were postponed as L'Aquila was hit by a severe earthquake in April 2009.
} 


\section{The Data}

We collected municipal-level data of provincial and municipal elections held in 2004 and 2009. ${ }^{5}$ We then collected data on local government officials, such as mayors and provincial presidents, and their political affiliation. Both of these sets of data are made public by the Interior Ministry. From the national statistical office (ISTAT), we also collected demographic data on municipalities, such as population, the share of children, elderly and foreigners, the average declared personal income-tax base (source: Finance Ministry).

As political controls we constructed variables capturing the ideological complexion of the ruling coalition at the provincial (left/right) and municipal (left/right/local voters' association) level, whether the incumbent provincial president or mayor are subject to a term limit, and whether the incumbent mayor and provincial president belong to the same political coalition (align), and how many year the incumbent mayor has been in office.

The municipality is our unit of observation: in other words we observe the electoral behaviour in any electoral contest (municipal, provincial) at the municipality level. For each election we construct a number of measures. First of all, the number of votes cast, as a share of eligible voters (turnout), then the number of valid votes cast as a share of eligible voters (net turnout) and the share of invalid (i.e. spoiled and blank) ballots, as a share of eligible voters.

We also construct measures of votes (in provincial elections) obtained by the coalition ruling at the provincial level (incumbent), by the opposing coalition (challenger), and the difference between these two, i.e the margin of victory of the incumbent ( $m v$, which is negative if the incumbent loses the elections).

Provincial fiscal performance is captured by per capita tax revenues (Entrate Tributarie). This measures captures the province-wide fiscal policy, and is therefore invariant within each province/provincial term of office. We we expect it to have a detrimental impact on the popularity of the incumbent government. Similarly, we take total per-capita municipal tax revenues as an inverse indicator of municipal government performance, and expect it to have both a direct negative on incumbent mayors, and possibly an indirect negative spill-over effect on the popularity of same-party provincial incumbents. All monetary values are deflated.

\footnotetext{
${ }^{5}$ We choose these two years as they are the only ones in which no other higher-salience election was held: in 2001, 2006 and 2008 general elections were held. In 2000, 2005 and 2010 many regional government went to elections. In other years very few mayors and provinces were elected.
} 


\section{Empirical Strategy and Results}

We are interested in two phenomena related with concurrent elections. First, its effect on turnout; second, how voters' ability of holding politicians accountable is affected by concurrence.

We perform an OLS analysis of all municipalities in which provincial elections are held for year 2004 and 2009. When looking at turnout, our main specification is the following:

$$
y_{i t}=\alpha+\beta M_{i t}+\gamma X_{i t}+\phi_{p}+\tau_{t}+\varepsilon_{i t}
$$

where $y$ is in turn (1) net turnout at the municipal level (validly cast ballots over registered voters), (2) invalid ballots (spoiled and blank ballots over registered voters), $M$ is a dummy variable taking value 1 if mayoral elections are held in the same day, $X$ is a battery of controls. Province fixed effects are also added, and errors are clustered at the province level. As controls we include political controls (whether mayor and provincial presidents are barred from seeking re-election because of the term limit, and whether they are politically aligned), demographic controls (population, share of children, elderly and foreigners) and average income tax base.

Table 5 shows evidence that municipalities with concurrent mayoral elections had an increase of about $6 \%$ in validly cast ballots (Net Turnout, columns 1-3). From columns 4-6 we can see that also spoiled and blank ballots increased by over $3 \%$. These results are hardly affected by the inclusion of controls (columns 2 and 5), and when we restrict our sample to municipalities with partisan mayors (columns 3 and 6 , more on this later). This shows that roll-off is a relevant phenomenon also in Italy, but it accounts for less than half of the extra turnout caused by concurrent election. Also some control variables show a significant effect; richer municipalities tend to vote more, and to have a smaller share of invalid ballots. This is also consistent with evidence on the effect of concurrence on the turnout to Italian mayoral elections (Revelli, 2017).

Having established that the decision to turn out is affected by the concurrence of elections, we now turn to the main focus of this paper, which is electoral accountability. Our aim is to see whether and how voters are able (or willing) to hold into account politicians when they are faced with more than one election at the same time. To do this, we focus on a number of variables that we believe proxy well the perceived performance of provincial presidents and mayors.

Our identification strategy is fairly simple, as we rely on the independence of mayoral terms across space within each province: 


$$
\begin{aligned}
m v_{i t} & =\alpha+\beta M_{i t}+ \\
& +\delta_{1} M_{i t} * \operatorname{PROVPerf}_{i t}+\delta_{2}\left(1-M_{i t}\right) * \operatorname{PROVPerf}_{i t}+ \\
& +\delta_{3} M_{i t} * \operatorname{MUNICPerf}_{i t}+\delta_{4}\left(1-M_{i t}\right) * \operatorname{MUNICPerf}_{i t}+ \\
& +\gamma X_{i t}+\phi_{r}+\tau_{t}+\varepsilon_{i t}
\end{aligned}
$$

where $m v$ is the provincial incumbent's margin of victory at the municipal level, PROVPerf is our measure of provincial performance (invariant for each province-year), MUNICPerf is the measure of municipal performance, $X$ is the same battery of political, economic and demographic controls described for the turnout regressions. We include area and time fixed effects, and concentrate on municipalities in which a partisan mayor is in power, in order to focus on localities where there is a "partisan" polity in both tiers. We decided to interact performances both with $M$ and its complement to ease the exposition of the results, i.e. to highlight the differentiated impact of fiscal performances in the treatment and control groups.

We believe that it is highly unlikely that provincial elections outcomes at the municipal level affect mayoral fiscal choices, thus creating problems of endogeneity. Even less likely is that provincial fiscal choices - which are valid for the whole province at large - are caused by municipal-level voting at provincial elections.

Tables 6 shows our main results. In Column 1 we present the regression with demographic and economic controls, and the fixed effects. In Column 2 we add the political controls, and in Column 3 we interact the municipal performances with the alignment dummy.

At first glance, we can observe how provincial performance is consistently significant across specification under non-concurrent elections $\left(\delta_{2}\right)$, while municipal performance affects provincial voting behaviour only under concurrent elections $\left(\delta_{3}\right)$. More precisely, we also test that each provincial performance is significantly stronger when elections are not held concurrently, and that each municipal performance is significantly stronger when elections are not held concurrently. At the bottom of Table 6 the results of these tests are shown. With a $95 \%$ confidence we can state that provincial performance matters more when provincial elections are not "contaminated" by municipal ones. As for municipal performance, this result is less stark: with only $90 \%$ confidence we can say that municipal performance affects provincial elections more under concurrent elections (once we add political controls, Column 2).

Looking at the results in Column 2 , we can say that a 1 Euro increase in provincial per-capita tax revenues generates a $0.6 \%$ drop in the provincial incumbent margin of victory in absence of concurrent elections. Similarly a 1 Euro increase in per-capita municipal taxes 
generates a $0.014 \%$ decrease in the provincial incumbent margin of victory in presence of concurrent municipal elections. Regarding this last result, though, one has to remember that we are only $90 \%$ confident that this effect is stronger in the treatment than in the control group. The magnitude of these two effects are also quite different, but it is worth reminding that municipal per capita tax revenues are about four times provincial per-capita revenues (see Table 4).

As anticipated in the theoretical section, partisan alignment may well play a role in voters' mind when using information across tiers of government. In Column 3 we interact the municipal performance variables with alignment. This generally strengthens our results, somehow confirming how the interaction of ideological allegiances in the two tiers matter substantially.

The point estimates are hardly changed in Column 3, but their interpretation is slightly more challenging. We can now state with $95 \%$ confidence that municipal fiscal performance affects provincial-elections voting behaviour only under concurrence, and that this effect is significantly stronger than under non-concurrent elections (test on $\delta_{3}$ and $\delta_{4}$ at the bottom of the table); mind that these findings are now to be ascribed to unaligned municipalities. Also for aligned municipalites, we can say with $90 \%$ confidence that municipal performace affects voting behaviour under concurrent elections $\left(\delta_{3}+\delta_{5}\right.$, bottom of the Table), but not under non-concurrent elections $\left(\delta_{4}+\delta_{6}\right.$, bottom of the Table).

These results broadly support our theoretical intuition: not only concurrent elections raise voter turnout, but they also tend to affect voting behavior. We found evidence that voters stop responding (or respond less) to own-election parameters when a more salient contest is under way. With more caution, we can also state that when a more salient contest is held, the performance of that incumbent affects the voting outcomes of the less salient contest. The interaction of our variables of interest with partisan alignment strengthen these results, but no specific alignment-related pattern emerges.

Most of the other control variables are non significant, probably also because of the presence of fixed effects. The only notable exception is the ideological alignment between provincial president and mayor. It is highly significant both in the treatment and control group in both tables. This obviously picks up on the ideological "homogeneity" of voters in a given location.

All in all our results confirm the theoretical intuitions that concurrence affects the information of voters and the ability of voters to hold politicians into account: voters are shown to "react" to provincial policies as long as provincial elections are the main item on the ticket. When the ticket also includes (more salient) mayoral elections, voters punish and reward the provincial incumbent looking at the behaviour of the incumbent mayor. 


\section{Robustness checks}

Our experimental design relies on two main features. First, on the randomness of the mayoral terms of office within each province. This is of little concern as it is the outcome of decades of events in local polities that little have to do with accountability and voting behaviour in our sample period. It also seems unreasonable to think that local politicians would push for early elections in order to strategically opt into the concurrent (or non-concurrent) election cycle. New elections are called if the CEO resigns or dies, or if a majority of the council passes a no-confidence motion. In both of these instances, it would be the ruling partyexpressing the CEO and the majority of the Council - to decide to "gamble" a new elections, thus shortening the term in office.

Second, we need to be sure that our results are not driven by specific characteristics of the municipalities included in the two groups. The large array of fixed effects and control variables included in our analysis addresses at least partially these concerns. On the other hand, a closer look at these characteristics across municipalities shows that the treatment and control groups are substantially different in their observables.

In Table 8 we can see how the treatment group includes municipalities which are on average "older", with a stronger presence of immigrants, and with fewer inhabitants.

To overcome this we make use of a balancing non-parametric technique that relies on Propensity Scores (Imbens, 2004; Caliendo and Kopeinig, 2008). We calculate the propensity of scores of being in the treatment group, using the same demographic and economic controls as in our main regressions, excluding political variables, and including time and province fixed effects. We chose this specification as we are aiming at "predicting" the probability of being in the treatment group irrespective of any political dynamic, as voting behaviour is the outcome variable we want to predict with our regressions. The weights obtained through this are then utilised as regression weights to re-run the regressions as in Tables 6 . This allows us to balance the treatment and control groups, and run our main regressions with (forcefully) balanced treatment and control groups. In Table 9 we show the weighted means of covariates in treatment and control group, which are now balanced.

To insure that propensity score is appropriate to our data, we need to check that treatment and control groups have a common support. A plot of the propensity scores in Treatment and Control group is shown in Figure 1: all observation are included in the common support. We can also argue that the conditional independence assumption is also fulfilled, given the "selection" mechanism into the treatment group. Our weights are calculated through a logit nearest neighbour algorithm; use of alternative algorithms gives analogous results.

The results of these regressions are shown in Tables 7 . The point estimates are almost 
identical to the ones in Table 6; through this process some effects that were previously at the margins of significance see their robustness increased. Looking at the results in Column 2 , we can say that a 1 Euro increase in provincial per-capita tax revenues generates a $0.559 \%$ drop in the provincial incumbent margin of victory if provincial elections are held non-concurrently. Similarly a 1 Euro increase in per-capita municipal taxes generates a $0.016 \%$ decrease in the provincial incumbent margin of victory if provincial elections are held together with the municipal ones. Both of these results are now significant at the $95 \%$ confidence level. In Column 3 we can see once again what happens when we interact the municipal performance variable with the alignment dummy.

We can now state with 95\% confidence that municipal performance affects provincialelections voting behaviour both in aligned and unaligned municipalities under concurrence (see resp. $\delta_{3}+\delta_{5}$ at the bottom and $\delta_{3}$ in the main panel of Table 7 ), and that this effect is significantly stronger than under non-concurrent elections. The interaction with the alignment dummies does not give us strong assurances on whether what is observed is to be ascribed to voters rewarding provincial presidents who are co-partisan to mayors who cut taxes.

\section{Conclusions}

The literature studying the consequences of holding elections for different tiers of government separately or concurrently has focused on the impact of the timing of elections on voter turnout rates and on the type of policies that are implemented by governments that are elected in elections with different degrees of voter participation. Concomitant elections are generally praised for raising voter turnout - a result that passes most empirical tests and that is confirmed in our analysis too. Using the quasi-experimental conditions of having a control group of Italian municipalities that only experience provincial (upper-tier) elections whose stakes are considered to be low, and a treatment group of municipalities that face both provincial and mayoral (lower-tier) elections whose stakes are considered to be high on the very same day, we find turnout rates to be higher by almost ten percentage points in the treatment group, and valid votes to be higher by about six percentage points. However, we also argue that the concomitance of elections might hinder the accountability of lower stakes government incumbents. This would be the case if the policy implemented by the higher stakes government having elections on the same day has a spill-over onto the popularity of incumbents of the lower-stakes tier by attracting voters' attention. In other words, voters would acquire more easily the information on the most visible and salient policy, and would vote in both elections by taking it into account at the expense of the less visible and less 
salient policy.

Indeed, our results show that the more salient contest (mayoral elections) affects the less salient one (provincial elections), with voting behaviour in the latter turning out to be insensitive to own policy (provincial tax burden), but responding instead to the performance of politicians - municipal tax burdens - of the former one. These findings shed light on how voters acquire information on incumbent politicians, and prove that the effectiveness of local elections as an accountability tool may, in spite of the apparently desirable increase in voter turnout that is observed in "election day" voting schemes, be hindered by the decision of holding them concurrently with more salient and higher stakes ones. 


\section{References}

Ahn, D. S. and S. Oliveros (2012). Combinatorial voting. Econometrica 80(1), 89-141.

Ahn, D. S. and S. Oliveros (2014). The condorcet jur(ies) theorem. Journal of Economic Theory 150, $841-851$.

Akhmedov, A. and E. Zhuravskaya (2004). Opportunistic political cycles: test in a young democracy setting. The Quarterly Journal of Economics 119(4), 1301-1338.

Alesina, A. and H. Rosenthal (1995). Partisan politics, divided government, and the economy. Cambridge University Press.

Anzia, S. F. (2011). Election timing and the electoral influence of interest groups. The Journal of Politics 73(2), 412-427.

Anzia, S. F. et al. (2012). The election timing effect: Evidence from a policy intervention in texas. Quarterly Journal of Political Science 7(3), 209-248.

Augenblick, N. and S. Nicholson (2016). Ballot position, choice fatigue, and voter behaviour. The Review of Economic Studies 83(2), 460.

Berry, C. R. and J. E. Gersen (2011). Election timing and public policy. Quarterly Journal of Political Science 6(2), 103-135.

Bhattacharya, S., J. Duffy, and S.-T. Kim (2014). Compulsory versus voluntary voting: An experimental study. Games and Economic Behavior 84, 111 - 131.

Bianchini, L. and F. Revelli (2013). Green polities: Urban environmental performance and government popularity. Economics \& Politics 25(1), 72-90.

Borgers, T. (2004, March). Costly Voting. American Economic Review 94(1), 57-66.

Brender, A. (2003). The effect of fiscal performance on local government election results in israel: 1989-1998. Journal of Public Economics 87(9-10), 2187 - 2205.

Caliendo, M. and S. Kopeinig (2008). Some practical guidance for the implementation of propensity score matching. Journal of economic surveys 22(1), 31-72.

Degan, A. and A. Merlo (2007, February). A Structural Model of Turnout and Voting in Multiple Elections, Fourth Version. PIER Working Paper Archive 07-025, Penn Institute for Economic Research, Department of Economics, University of Pennsylvania. 
Dhillon, A. and S. Peralta (2002). Economic theories of voter turnout. The Economic Journal 112(480), F332-F352.

Drazen, A. and M. Eslava (2010). Electoral manipulation via voter-friendly spending: Theory and evidence. Journal of development economics 92(1), 39-52.

Feddersen, T. and W. Pesendorfer (1996). The swing voter's curse. The American Economic Review 86(3), 408-424.

Gerardi, D., M. A. McConnell, J. Romero, and L. Yariv (2009). Get Out the (Costly) Vote: Institutional Design for Greater Participation. Technical report.

Geys, B. and J. Vermeir (2008, June). Party cues and yardstick voting. European Journal of Political Economy 24(2), 470-477.

Ghirardato, P. and J. N. Katz (2000, November). Indecision Theory: Explaining Selective Abstention in Multiple Elections. Working Papers 1106, California Institute of Technology, Division of the Humanities and Social Sciences.

Ghosal, S. and B. Lockwood (2009, June). Costly voting when both information and preferences differ: is turnout too high or too low? Social Choice and Welfare 33(1), 25-50.

Hajnal, Z. and J. Trounstine (2005). Where turnout matters: The consequences of uneven turnout in city politics. Journal of Politics 67(2), 515-535.

Halberstam, Y. and B. P. Montagnes (2015). Presidential coattails versus the median voter: Senator selection in us elections. Journal of Public Economics 121, 40 - 51.

Imbens, G. W. (2004). Nonparametric estimation of average treatment effects under exogeneity: A review. Review of Economics and statistics 86(1), 4-29.

Jones, M. P., O. Meloni, and M. Tommasi (2012). Voters as fiscal liberals: Incentives and accountability in federal systems. Economics 83 Politics 24 (2), 135-156.

Krasa, S. and M. K. Polborn (2009, May). Is mandatory voting better than voluntary voting? Games and Economic Behavior 66(1), 275-291.

Lijphart, A. (1997). Unequal participation: Democracy's unresolved dilemma presidential address, american political science association, 1996. American political science review $91(01), 1-14$.

Lo Prete, A. and F. Revelli (2014, November). Voter Turnout and City Performance. Working papers 10, Società Italiana di Economia Pubblica. 
Martinelli, C. (2006, July). Would rational voters acquire costly information? Journal of Economic Theory 129(1), 225-251.

Martinelli, C. (2011). Ignorance and Naivete in Large Elections. Technical report.

Matejka, F. and G. Tabellini (2015, October). Electoral Competition with Rationally Inattentive Voters. CEPR Discussion Papers 10888, C.E.P.R. Discussion Papers.

Noury, A. (2004, October). Abstention in Daylight: Strategic Calculus of Voting in the European Parliament. Public Choice 121(1), 179-211.

Oliveros, S. (2013). Abstention, ideology and information acquisition. Journal of Economic Theory 148(3), 871-902.

Peltzman, S. (1992). Voters as fiscal conservatives. The Quarterly Journal of Economics $107(2), 327-361$.

Revelli, F. (2008). Performance competition in local media markets. Journal of Public Economics 92(7), 1585-1594.

Revelli, F. (2017). Voter turnout in italian municipal elections, 2002-2013. Italian Economic Journal, 1-15.

Sakurai, S. N. and N. A. Menezes-Filho (2008). Fiscal policy and reelection in brazilian municipalities. Public Choice 137(1-2), 301-314.

Veiga, L. G. and F. J. Veiga (2007). Does opportunism pay off? Economics Letters 96(2), $177-182$.

Wittman, D. (1989). Why democracies produce efficient results. Journal of Political Economy 97(6), 1395-1424.

Wolfers, J. (2002). Are voters rational?: Evidence from gubernatorial elections. Graduate School of Business, Stanford University.

Zudenkova, G. (2011). A political agency model of coattail voting. Journal of Public Economics 95(11-12), 1652 - 1660. Special Issue: International Seminar for Public Economics on Normative Tax Theory. 
Table 1: Provinces' Consolidated Budgets, 2004.

\begin{tabular}{|l|l|l|l|}
\hline \multicolumn{2}{|l|}{ Current Revenues } & Current Expenditures \\
\hline Tax Revenues & $50 \%$ & General Administration & $29 \%$ \\
\hline Grants & $42 \%$ & Education & $22 \%$ \\
\hline Fees and Charges & $8 \%$ & Roads & $12 \%$ \\
\hline & & Transport & $11 \%$ \\
\hline & & Economic Dev. & $11 \%$ \\
\hline & & Environment & $7 \%$ \\
\hline & & Social & $3 \%$ \\
\hline & & Tourism & $3 \%$ \\
\hline & & Culture & $3 \%$ \\
\hline
\end{tabular}

Table 2: Municipalities' Consolidated Budgets, 2004.

\begin{tabular}{|l|l|l|l|}
\hline \multicolumn{2}{|c|}{ Current Revenues } & \multicolumn{2}{c|}{ Current Expenditures } \\
\hline Total Tax Revenues: & $52 \%$ & General Administration & $32 \%$ \\
\hline Grants & $28 \%$ & Environment & $19 \%$ \\
\hline Fees and Charges & $22 \%$ & Social & $14 \%$ \\
\hline & & Education & $10 \%$ \\
\hline & & Transport and Traffic & $9 \%$ \\
\hline & & Local police & $6 \%$ \\
\hline & & Licensing and trade & $1 \%$ \\
\hline & & Economic Dev. & $1 \%$ \\
\hline & & Tourism & $1 \%$ \\
\hline & & Justice & $1 \%$ \\
\hline
\end{tabular}

Table 3: Summary statistics — Full Sample

\begin{tabular}{lccccc}
\hline \hline \multicolumn{1}{c}{ Variable } & Mean & Std. Dev. & Min. & Max. & N \\
\hline Net Turnout & 0.674 & 0.095 & 0.11 & 0.971 & 8774 \\
\% Invalid ballots & 0.071 & 0.035 & 0 & 0.312 & 8774 \\
mv & 11.895 & 28.095 & -87.617 & 93.75 & 8543 \\
M & 0.652 & 0.476 & 0 & 1 & 8779 \\
PROVperf (Tax Rev.) & 70.116 & 14.04 & 37.64 & 98.159 & 8779 \\
MUNICperf (Tax Rev.) & 305.378 & 187.297 & 31.831 & 3741.173 & 8775 \\
Align & 0.247 & 0.431 & 0 & 1 & 8779 \\
Termlimited PresProv & 0.396 & 0.489 & 0 & 1 & 8779 \\
Termlimited Mayor & 0.283 & 0.45 & 0 & 1 & 8779 \\
Share children & 13.008 & 2.785 & 0 & 24.926 & 8779 \\
Share elderly & 22.6 & 6.307 & 6.169 & 63.265 & 8779 \\
Share foreign & 4.92 & 3.697 & 0 & 26.439 & 8779 \\
Income tax base & 14.29 & 3.007 & 5.467 & 32.592 & 8746 \\
Pop, 000 & 6.645 & 25.418 & 0.036 & 987.984 & 8779 \\
\hline
\end{tabular}


Table 4: Summary statistics — Only non-partisan mayors

\begin{tabular}{lccccc}
\hline \multicolumn{1}{c}{ Variable } & Mean & Std. Dev. & Min. & Max. & N \\
\hline Net Turnout prov & 0.676 & 0.087 & 0.206 & 0.941 & 3055 \\
\% Invalid Ballots & 0.065 & 0.03 & 0.005 & 0.23 & 3055 \\
mv & 15.422 & 25.405 & -74.528 & 87.136 & 2957 \\
M & 0.555 & 0.497 & 0 & 1 & 3056 \\
PROV_perf (Tax Rev.) & 67.619 & 15.545 & 37.64 & 98.159 & 3056 \\
MUNIC_perf (Tax Rev.) & 297.218 & 145.744 & 31.831 & 1628.15 & 3053 \\
Align & 0.692 & 0.462 & 0 & 1 & 3056 \\
Termlimited PresProv & 0.469 & 0.499 & 0 & 1 & 3056 \\
Termlimited Mayor & 0.257 & 0.437 & 0 & 1 & 3056 \\
Share children & 13.579 & 2.518 & 0 & 24.76 & 3056 \\
Share elderly & 21.37 & 5.36 & 6.92 & 62.791 & 3056 \\
Share foreigners & 4.735 & 3.665 & 0 & 22.645 & 3056 \\
Income Tax base & 14.095 & 3.214 & 5.804 & 32.592 & 3043 \\
Pop, 000 & 13.569 & 41.552 & 0.043 & 987.984 & 3056 \\
\hline
\end{tabular}




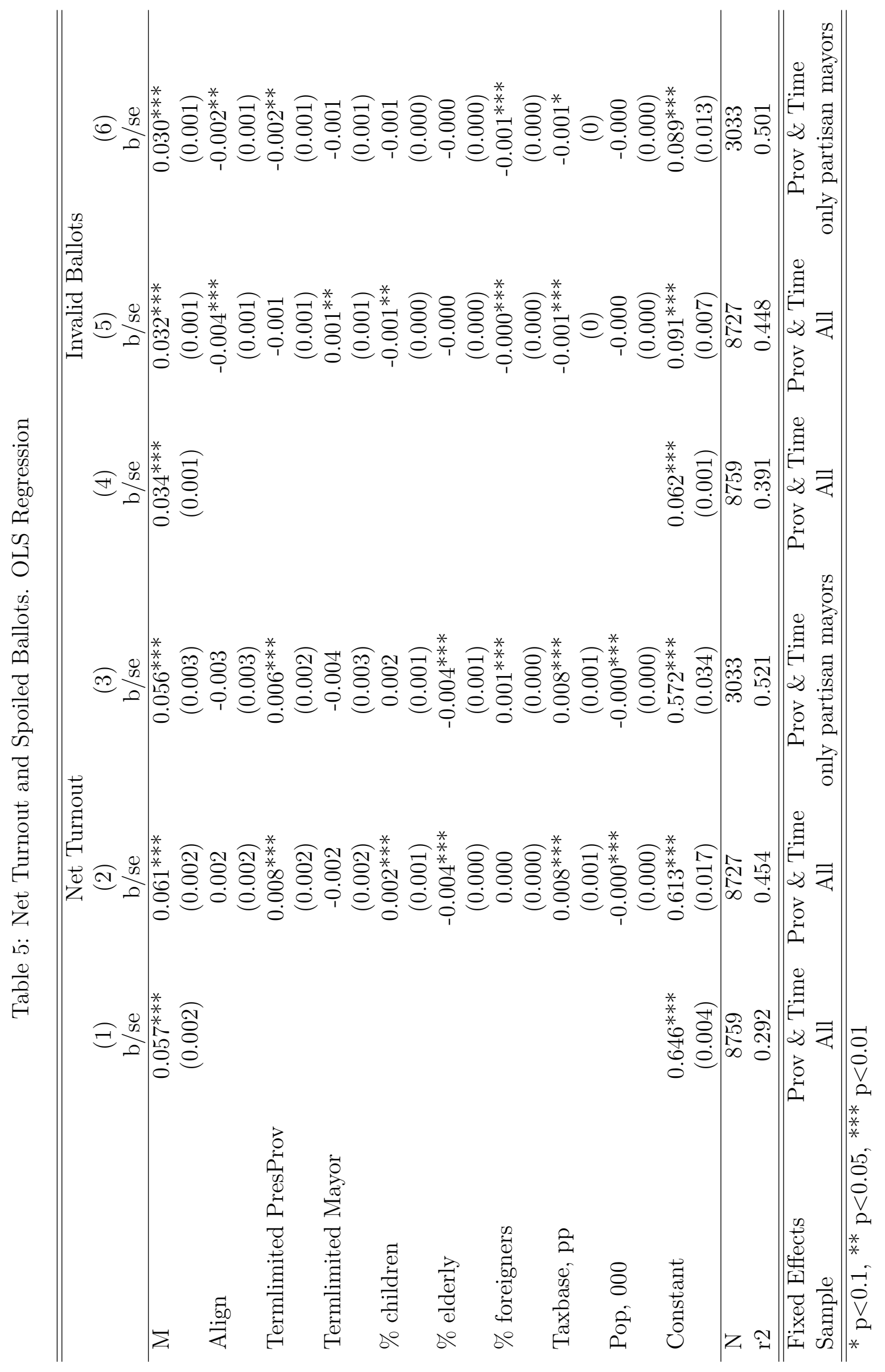


Table 6: Effect of Provincial and Municipal fiscal performance on Provincial Elections. OLS Results.

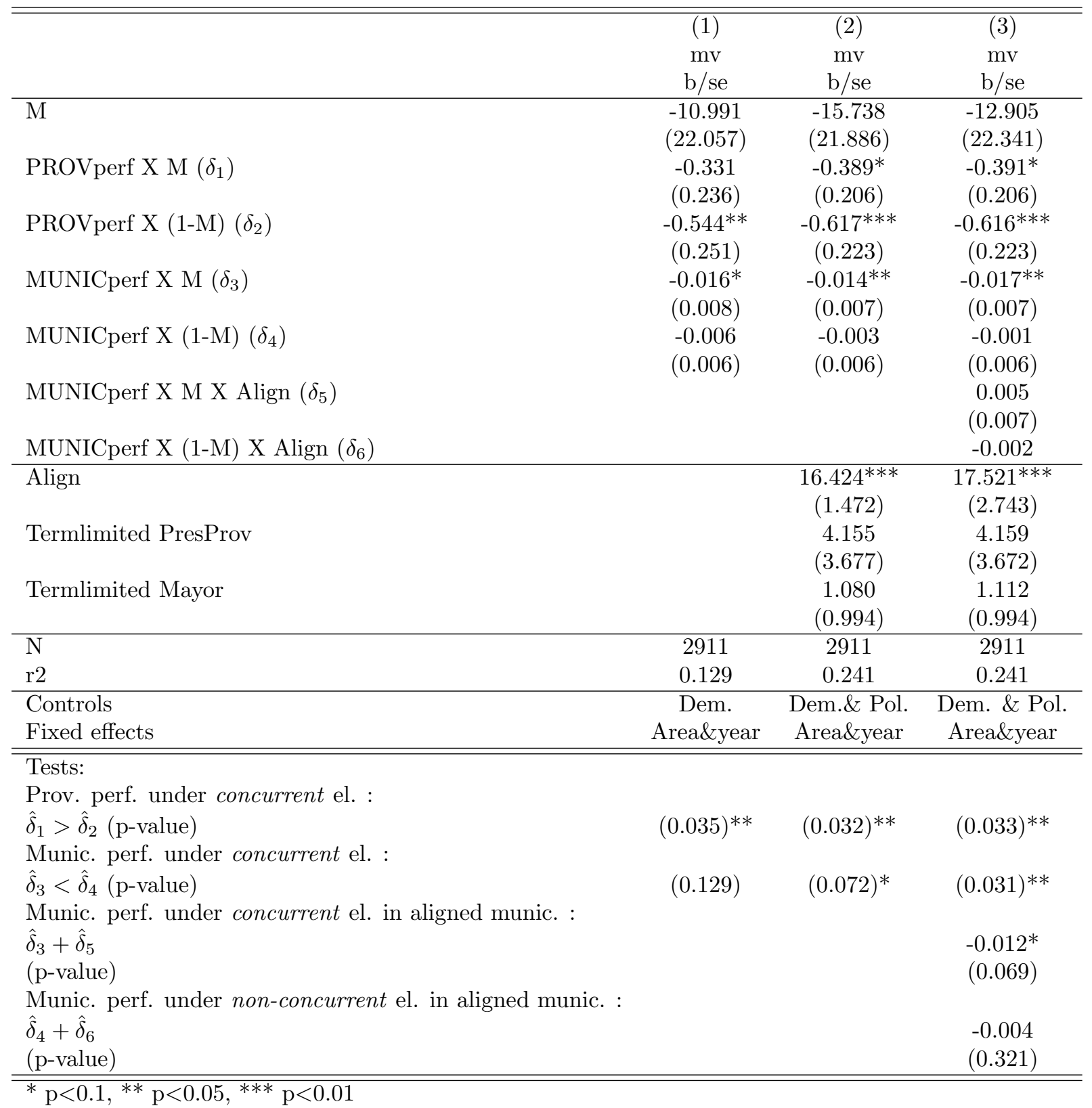


Table 7: Effect of Provincial (expenditure) and Municipal (tax-revenue) "performance" on Provincial Elections. Weighted Results.

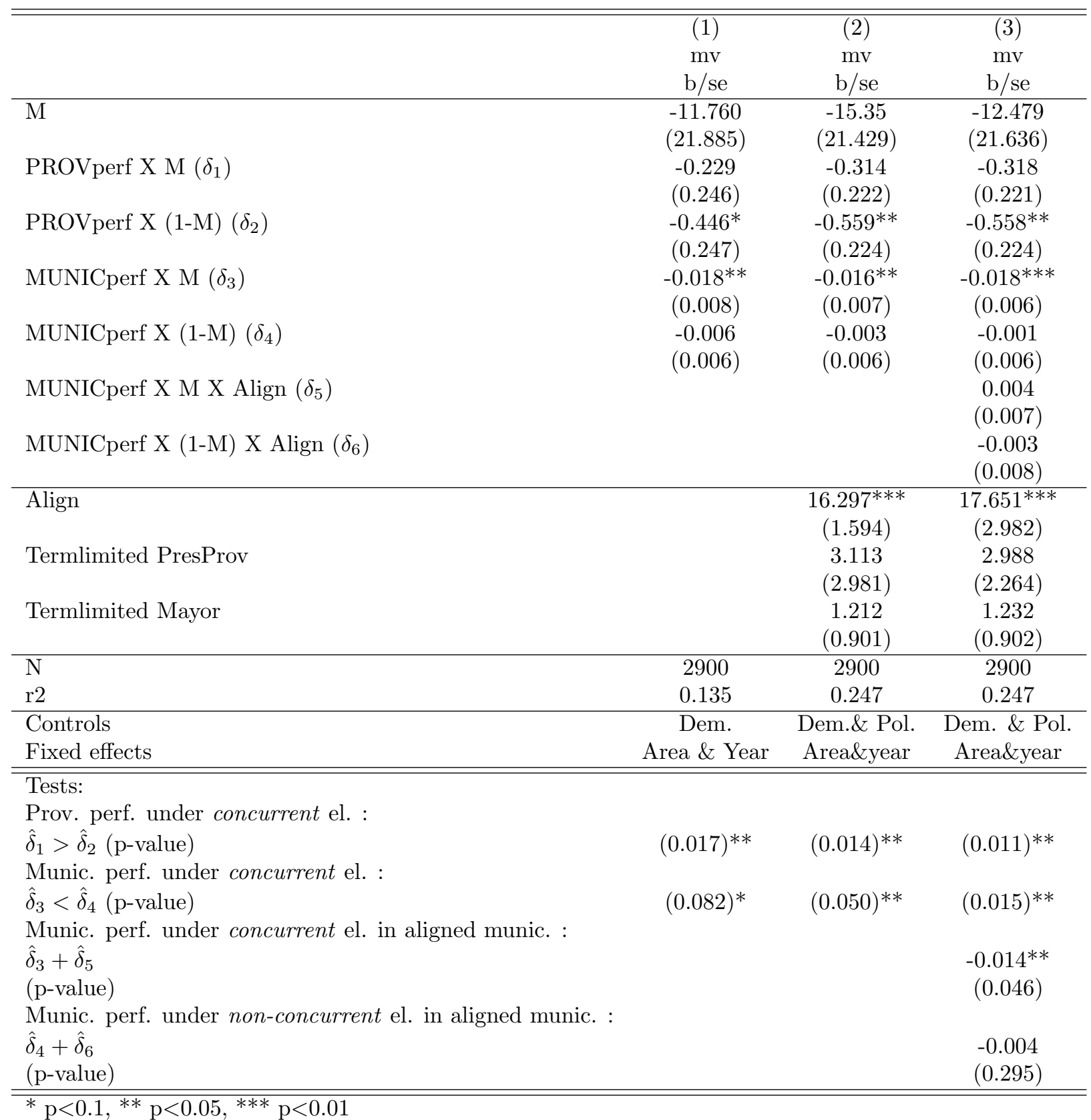

Table 8: Mean Difference: Control and Treatment Groups

\begin{tabular}{|l|cccc|}
\hline & Control & Treatment & $\mathrm{t}$ & $p>|t|$ \\
\hline Share elderly & 20.21 & 21.98 & -9.08 & 0.00 \\
share children & 14.18 & 13.23 & 10.23 & 0.00 \\
share foreigners & 3.82 & 5.51 & -12.80 & 0.00 \\
Income, pp. & 13.73 & 14.36 & -5.28 & 0.00 \\
Pop, 000 & 18.03 & 11.09 & 4.47 & 0.00 \\
\hline
\end{tabular}


Table 9: Mean Difference: Control and Treatment Groups with PS weights

\begin{tabular}{|l|cccc|}
\hline & Control & Treatment & $\mathrm{t}$ & $p>|t|$ \\
\hline Share elderly & 21.96 & 21.97 & -.12 & 0.90 \\
share children & 13.26 & 13.24 & .014 & 0.97 \\
share foreigners & 5.82 & 5.50 & -2.43 & 0.01 \\
Income, pp. & 14.35 & 14.19 & 0.94 & 0.35 \\
Pop, 000 & 18.03 & 11.09 & 1.51 & 0.13 \\
\hline
\end{tabular}


Figure 1: Propensity scores of treated and untreated groups.

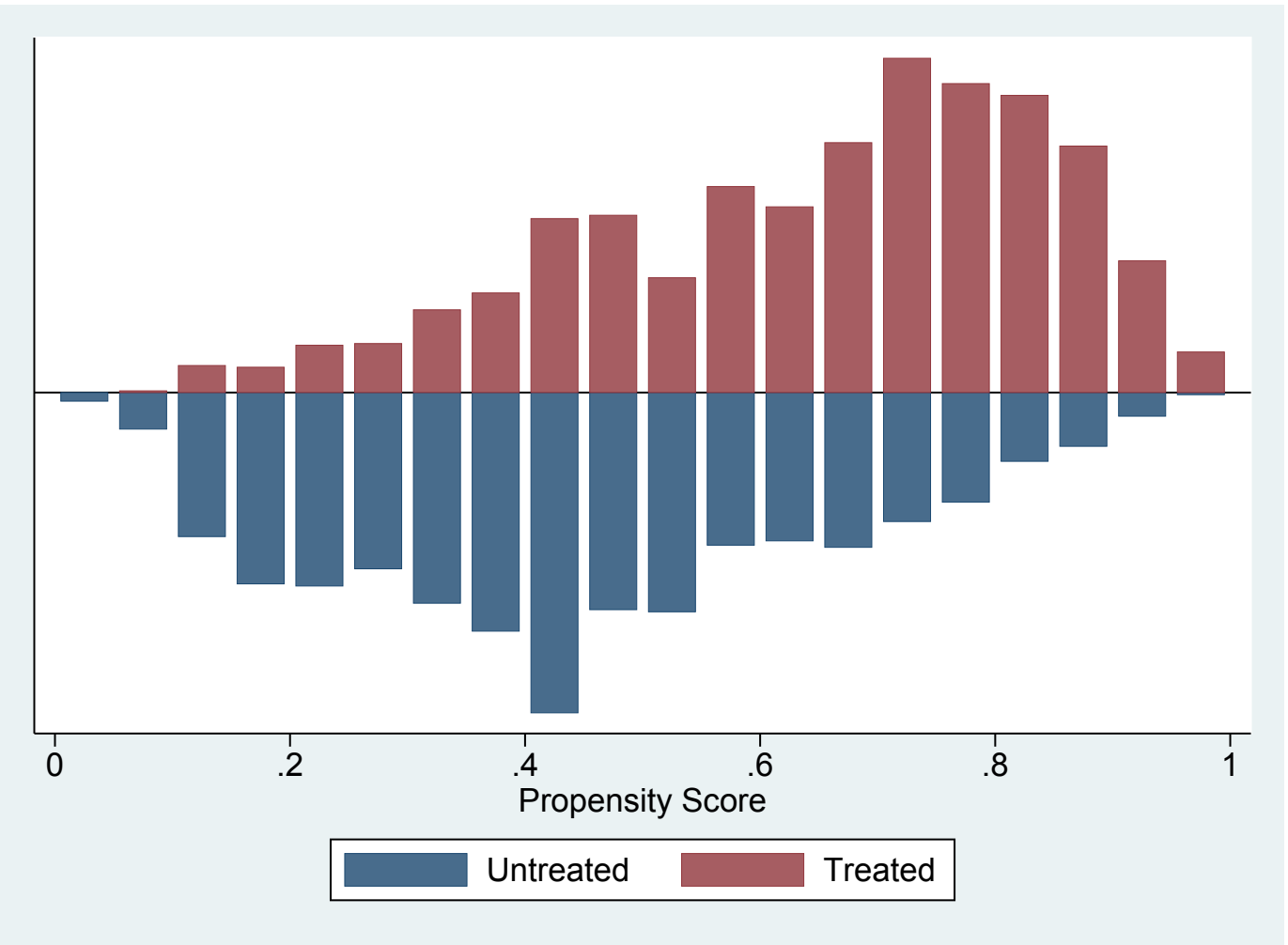

